\title{
Ca and Atherosclerosis
}

\author{
Hajime ORIMO, Kenzo TERASHITA, Tetsuro NAKAMURA, \\ and Joji OHSHIMA
}

Department of Geriatrics, University of Tokyo, Tokyo 113, Japan

\section{Aging and arterial calcification}

It has been well known that the incidence of arterial calcification increases with advancing age. As shown in Fig. 1, the incidence of calcification of the trachea, thoracic aorta, abdominal aorta and femoral artery in the so-called healthy subjects increased linearly with advancing age. To clarify the mode of $\mathrm{Ca}$ deposition in the artery, arterial calcification was induced in rats by giving large dose of $1 \alpha-\mathrm{OH}-\mathrm{D}_{3}$ and the susceptibility and reversibility of arterial calcification and the site of $\mathrm{Ca}$ deposition in the artery was studied. Male Fisher rats, 6 weeks old and 90 weeks old were given 5 or $10 \mu \mathrm{g} / \mathrm{kg} /$ day of $1 \alpha-\mathrm{OH}-\mathrm{D}_{3}$ for 10 days, and the $\mathrm{Ca}$ content of the aorta was measured. As shown in Fig. 2, Ca content in the aorta was significantly greater in the older rats than in the younger rats given $5 \mu \mathrm{g} / \mathrm{kg} /$ day of $1 \alpha-\mathrm{OH}-\mathrm{D}_{3}$, but not in the rats given $10 \mu \mathrm{g} / \mathrm{kg} /$ day of $1 \alpha-\mathrm{OH}-\mathrm{D}_{3}$. These results suggest that old rats were more susceptible to arterial calcification than young rats. To examine the reversibility of $\mathrm{Ca}$ deposition in the arterial wall, $\mathrm{Ca}$ content in the aorta was measured in the rats given $10 \mu \mathrm{g} / \mathrm{kg} /$ day of $1 \alpha-\mathrm{OH}-$ $D_{3}$ for 10 days, and in the rats given $10 \mu \mathrm{g} / \mathrm{kg} /$ day of $1 \alpha-\mathrm{OH}-\mathrm{D}_{3}$ for 10 days and then off the treatment for 10 days. As shown in Fig. 3, in the young rats aortic $\mathrm{Ca}$ content was significantly greater in the rats given $1 \alpha-\mathrm{OH}-\mathrm{D}_{3} 10 \mu \mathrm{g} / \mathrm{kg} /$ day for 10 days than in the rats given $1 \alpha-\mathrm{OH}-\mathrm{D}_{3} 10 \mu \mathrm{g} /$ $\mathrm{kg} /$ day for 10 days followed by off treatment for 10 days. On the other hand, in the old rats no significant difference in the aortic Ca content was found between these 2 groups. These results suggest the possibility that the arterial calcification is reversible in the young rats, but not in the old rats. Subsequently, to study the site of Ca deposition in the aorta, elastin and collagen were ex- tracted from the aorta, and $\mathrm{Ca}$ content in each fraction was measured. As shown in Fig. 4, Ca content was significantly greater in the elastin fraction than in the collagen fraction of the aorta of both young and old rats, following the treatment with $1 \alpha-\mathrm{OH}-\mathrm{D}_{3}$. These results suggest that $\mathrm{Ca}$ deposition mainly occurred in the elastin fraction of the aorta.

\section{Evaluation of new risk factors for arterial cal- cification}

To evaluate the role of risk factors for arterial calcification, 9 clinical data; age, sex, loss of bone mass, hypertension, glucose tolerance, Ht, serum fibrinogen, triglycerides and total cholesterol were checked in 271 cases with calcification of the thoracic aorta, and in 224 cases with calcification of the abdominal aorta, and in 200 cases with calcification of the femoral artery, respectively. And the correlation between these risk factors and arterial calcification was studied by using multivariate analysis. Figure 5 illustrates the example of such an analysis and Fig. 6 summarizes the correlation between risk factors and calcification of the thoracic, abdominal and femoral artery, respectively. Significant correlations between the risk factors and arterial calcification are shown below in the order of contribution; calcification of the thoracic aorta: loss of bone mass $>$ hypertension $>$ abnormal glucose tolerance, calcification of the abdominal aorta: sex $>$ loss of bone mass $>$ age $>$ hypertension $>$ plasma fibrinogen $>$ abnormal glucose tolerance, calcification of the femoral artery: hypertension $>$ abnormal glucose tolerance $>$ loss of bone mass $>$ age $>$ plasma fibrinogen $>$ serum triglyceride $>$ sex. Thus, it was shown that the loss of bone mass was an important new risk factor for arterial calcification, independent from the hitherto known risk factors. 


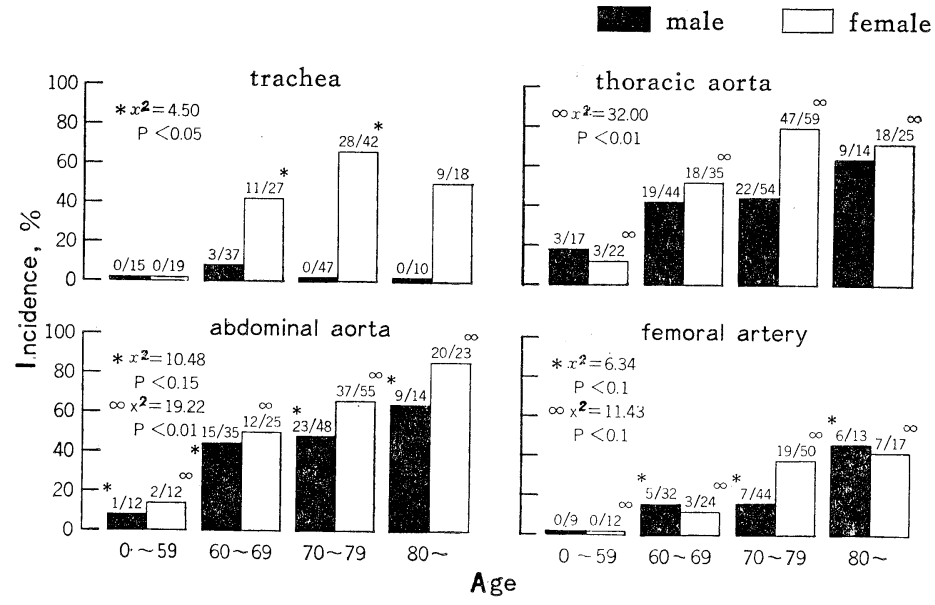

Fig. 1. Aging and soft tissue calcification.

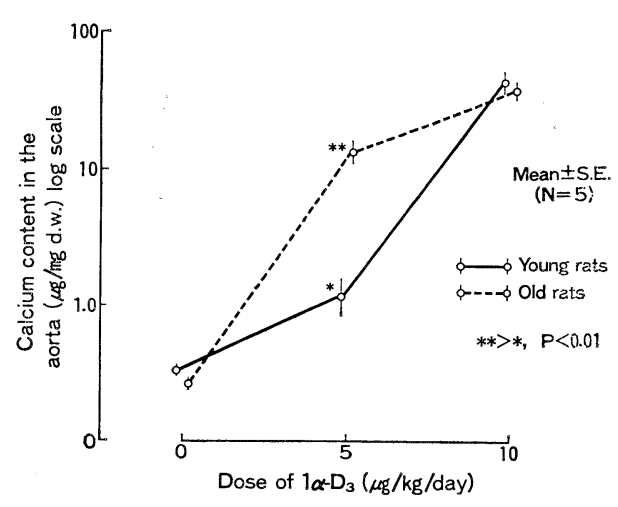

Fig. 2. Changes in $\mathrm{Ca}$ content of the aorta after $1 \alpha$ $\mathrm{D}_{3}$ administration.

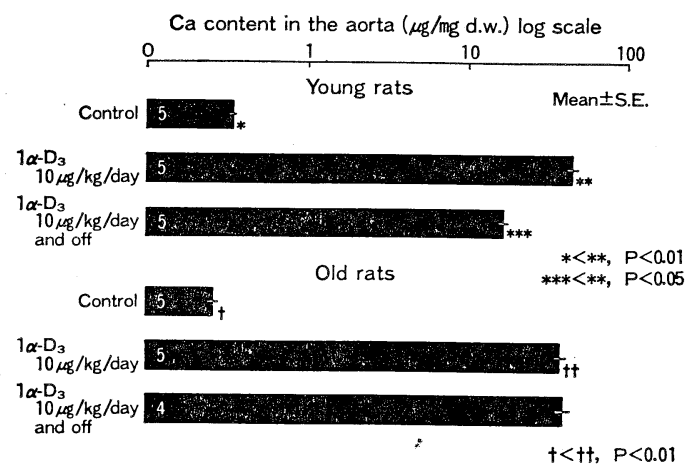

Fig. 3. Changes in $\mathrm{Ca}$ content of the aorta after $1 \alpha$ $\mathrm{D}_{3}$ administration.

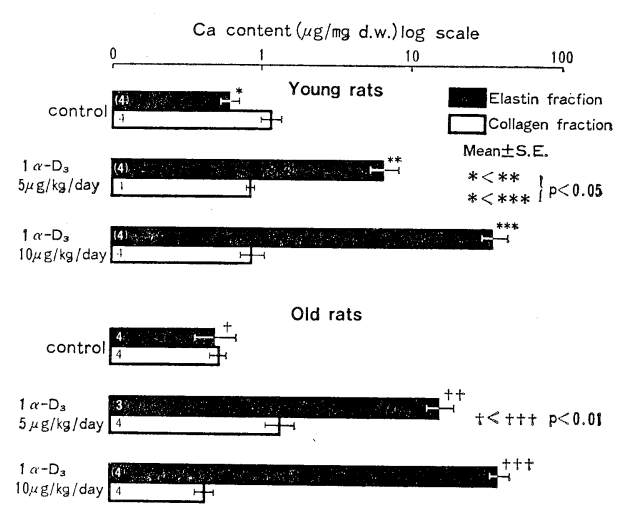

Fig. 4. Ca content in elastin and collagen fraction of the aorta.

\section{Ca shift with aging}

It has been well known that a loss of bone mass occurs with advancing age, while the occurrence of arterial calcification increases with advancing age. Furthermore, significant correlation was found between the loss of bone mass and the occurrence of arterial calcification. These facts will be explained by the assumption that with advancing age, $\mathrm{Ca}$ shift from the bone to the artery occurs. It is possible that with advancing age, $\mathrm{Ca}$ is mobilized from the bone due to increased bone resorption, and is deposited in the arterial wall, whose avidity to $\mathrm{Ca}$ is increased due to the denaturation of elastin in the media. To prove the validity of this hypothesis, rats with a 


\begin{tabular}{|c|c|c|c|}
\hline factor & category & 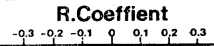 & P.C.C. \\
\hline age & $\begin{array}{l}60-59 \\
60-69 \\
70-79 \\
80-\end{array}$ & & $0.229^{*}$ \\
\hline sex & female male & & 0.239 \\
\hline bone loss & $\begin{array}{l}0^{\circ} \\
1^{\circ} \\
2^{\circ} \\
\end{array}$ & & $0.269^{* *}$ \\
\hline \begin{tabular}{|c|} 
hypertension \\
\end{tabular} & $(-) \quad(+)$ & & $0.382 * * *$ \\
\hline $\begin{array}{c}\text { glucose } \\
\text { tolerance }\end{array}$ & N,BL,DM & & $0.273^{* *}$ \\
\hline $\mathrm{Ht}$ & $\begin{array}{l}31=40 \\
41=40\end{array}$ & & 0.777 \\
\hline $\begin{array}{l}\text { serum } \\
\text { fibrinogen }\end{array}$ & $\begin{array}{l}201=200 \\
301=400 \\
401=500 \\
501=\end{array}$ & & 0.193 \\
\hline $\begin{array}{c}\text { serum } \\
\text { triglyceride }\end{array}$ & $\begin{array}{r}101=100 \\
\text { eie1 }=180 \\
\end{array}$ & & 0.136 \\
\hline $\begin{array}{c}\text { serum } \\
\mathrm{t} \text {-cholesterol }\end{array}$ & $\begin{array}{l}151=150 \\
201=200 \\
241= \\
\end{array}$ & & \\
\hline \multicolumn{3}{|c|}{$\begin{array}{l}\text { Contribution to calcification : hypertension } \\
\text { >glucose tolerance>bone loss >age }\end{array}$} & $\begin{aligned} * \mathrm{P}<0.05 \\
* * \mathrm{P}<0.01\end{aligned}$ \\
\hline
\end{tabular}

Fig. 5. Factors involved in the calcification of femoral artery.

progeria-like syndrome were used. Administration of large dose of dihydrotachysterol has been shown to induce loss of bone mass, accompanied by arterial calcification, which is quite similar to the changes in aged humans. When the rats, whose skeleton was prelabeled with ${ }^{45} \mathrm{Ca}$, were given large dose of dihydrotachysterol for 2 weeks, marked increases in $\mathrm{Ca}$ and ${ }^{45} \mathrm{Ca}$ in the aorta, heart and kidney were demonstrated (Fig. 7). These results clearly showed that the shift of $\mathrm{Ca}$ from the bone to the artery occurred in the rats with the progeria-like syndrome. In view of these data, it is possible that $\mathrm{Ca}$ shift may also occur in aged humans.

\section{Antiatherogenic effect of Ca channel blockers in experimental atherosclerosis}

Recently, Fleckenstein and his coworkers have

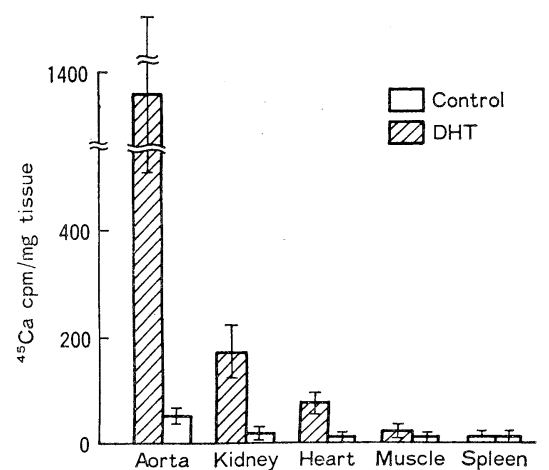

Fig. 7. Shift of ${ }^{45} \mathrm{Ca}$ from bone to soft tissues in the rats with progeria-like syndrome.

demonstrated that administration of nifedipine inhibited vitamin D-induced calcification of the artery in the spontaneously hypertensive rats (I). Furthermore, Henry has reported that nifedipine markedly inhibited the formation of atheroma in high cholesterol-fed rabbits (2). These observations strongly suggest the important role of $\mathrm{Ca}^{2+}$ in the pathogenesis of atherosclerosis. Since $\mathrm{Ca}^{2+}$ is involved in the diverse function of the platelet and/or arterial endothelial and smooth muscle cells, it is possible that $\mathrm{Ca}$ channel blockers may also alter the function of the platelet and arterial cells. It has been shown that $\mathrm{Ca}$ channel blockers inhibit the platelet aggregation in vitro, and also inhibit the migration of aortic smooth muscle cells in vitro. Thus, it is possible that the antiatherogenic effect of $\mathrm{Ca}$ channel blockers is mediated through the action of platelet and arterial cells. Further studies will be required to clarify the mechanism of antiatherogenic action of $\mathrm{Ca}$ channel blockers.

\begin{tabular}{|c|c|c|c|c|c|c|c|c|c|c|}
\hline & $n$ & age & sex & $\begin{array}{c}\text { bone } \\
\text { loss }\end{array}$ & $\begin{array}{c}\text { hyper- } \\
\text { tention }\end{array}$ & $\begin{array}{c}\text { glucose } \\
\text { tolerance }\end{array}$ & Ht & $\begin{array}{c}\text { plasma } \\
\text { fibrinogen }\end{array}$ & $\begin{array}{c}\text { serum } \\
\text { trifigceride }\end{array}$ & $\begin{array}{c}\text { serum } \\
\text { cholestelol }\end{array}$ \\
\hline $\begin{array}{c}\text { thoratic } \\
\text { aorta }\end{array}$ & 271 & 0.62 & 0.290 & 0.197 & 0.196 & & & & \\
\hline $\begin{array}{c}\text { abdominal } \\
\text { aorta }\end{array}$ & 224 & 0.223 & 0.263 & 0.236 & 0.217 & & & & & \\
\hline $\begin{array}{c}\text { femoral } \\
\text { artery }\end{array}$ & 200 & 0.229 & 0.269 & 0.382 & 0.273 & & & & \\
\hline
\end{tabular}

Fig. 6. Factors involved in the arterial calcification. 


\section{REFERENCES}

1) Fleckenstein, A., Frey, M., and von Witzleben, H. (1983): Vascular calcium overload-a pathogenic factor in arteriosclerosis and its neutralization by calcium antagonists. in 5th International Adalat Symposium, ed. by Kaltenbach, M., and Neufeld, H.N., Excerpta Medica, Amsterdam, p. 36.

2) Henry, P.D., and Bentley, K.I. (1981): Suppression of atherogenesis in cholesterol-fed rabbits treated with nifedipine. J. Clin. Invest., 68: 1366. 